\title{
Natural History and Cofactors
}

National Cancer Institute

\section{Source}

National Cancer Institute. Natural History and Cofactors. NCI Thesaurus. Code C16136.

Elucidation and description of disease progress 